NBER WORKING PAPER SERIES

\title{
EXPERIENCE OF AND LESSONS FROM EXCHANGE RATE REGIMES IN EMERGING ECONOMIES
}

\author{
Jeffrey A. Frankel \\ Working Paper 10032 \\ http://www.nber.org/papers/w10032 \\ NATIONAL BUREAU OF ECONOMIC RESEARCH \\ 1050 Massachusetts Avenue \\ Cambridge, MA 02138 \\ October 2003
}

This paper was written for Monetary and Financial Cooperation in East Asia forthcoming, Macmillan Press, 2003, in consultation with the Regional Economic Monitoring Unit of the Asian Development Bank, and Takatoshi Ito and Yung Chul Park, coordinators of the ADB core study on exchange rate arrangements. The author would like to thank Sergio Schmukler for preparing Table 3. The views expressed herein are those of the authors and not necessarily those of the National Bureau of Economic Research.

(C)2003 by Jeffrey A. Frankel. All rights reserved. Short sections of text, not to exceed two paragraphs, may be quoted without explicit permission provided that full credit, including (C) notice, is given to the source. 
Experience of and Lessons from Exchange Rate Regimes in Emerging Economies

Jeffrey A. Frankel

NBER Working Paper No. 10032

October 2003

JEL No. F3

\section{ABSTRACT}

The paper reviews recent trends in thinking on exchange rate regimes. It begins by classifying countries into regimes, noting the distinction between de facto and de jure regimes, but also noting the low correlation among proposed ways of classifying the latter. The advantages of fixed exchange rates versus floating are reviewed, including the recent evidence on the trade-promoting effects of currency unions. Frameworks for tallying up the pros and cons include the traditional Optimum Currency Area criteria, as well as some new criteria from the experiences of the 1990s. The Corners Hypothesis may now be "peaking" as rapidly as it rose, in light of its lack of foundations. Empirical evidence regarding the economic performance of different regimes depends entirely on the classification scheme. A listing of possible nominal anchors alongside exchange rates observes that each candidate has its own vulnerability, leading to the author's proposal to Peg the Export Price (PEP). The concluding section offers some implications for East Asia.

Jeffrey A. Frankel

Kennedy School of Government

Harvard University

79 JFK Street

Cambridge, MA 02138-5801

and NBER

jeffrey_frankel@harvard.edu 


\title{
Experience of and Lessons from Exchange Rate Regimes in Emerging Economies
}

\author{
Jeffrey A. Frankel
}

Emerging market countries in Latin America, East Asia, and Eastern Europe entered the 1990s with widely varying fundamentals. To over-generalize, Latin American countries before the 1990s traditionally had low national savings rates, profligate fiscal and monetary policies, and overvalued currencies, together with a large and growthinhibiting role of the government in the economy; however, most took very large steps in the right direction in the 1990s. East Asian countries had, already for some time, exhibited high national savings rates, greater monetary and fiscal discipline, and appropriately valued currencies, together with institutions of financial structure and government intervention that, though they differed from textbook market economics, appeared to be, if anything, more successful than Western-style capitalism, until the 1990s. Eastern European countries all entered the 1990s with institutions that had become universally discredited, but varied widely in their ability to establish macroeconomic stability and to make the transition to capitalist institutions.

Although these countries varied in their fundamentals - and varied further within the geographic groupings - all ended the 1990s as victims of severe financial turbulence in emerging markets. To name only the most spectacular cases, currency and financial crises hit Mexico in 1994; Thailand, Republic of Korea, and Indonesia in 1997; Russia in 1998; Brazil in 1999; and Turkey and Argentina in 2001. In most of these cases, the crisis had severe negative effects on economic growth. The causes of these crises have been widely debated, but it is difficult to attribute them solely to profligate monetary and fiscal policies because the East Asian countries had a strong record on this score, and Argentina had also moved very far to establish macroeconomic discipline in the 1990s.

Among other factors, exchange rate regimes have been implicated in most accounts of how these countries got into trouble.

Every one of the crisis victims named above was forced by large outflows to abandon an exchange rate target and to move to a regime of greater exchange rate flexibility. One school of thought has concluded that it was a mistake to have set explicit exchange rate pegs, and that the solution lies in increased exchange rate flexibility in the long term as well, perhaps in outright floating of the sort that Brazil and Mexico adopted after their crises (e.g., Obstfeld and Rogoff 1995 or Larrain and Velasco 2001).

Others have pointed out that none of the crises of the 1990s occurred in countries that had in fact been following explicit policies of tight exchange rate pegs. It is true that Thailand had been following a rather close de facto peg to the dollar over the 2 years preceding the July 1997 crisis. But - now usually forgotten-Thailand had in the early 1990s been one of those East Asian countries widely said to assign a large weight to the 
yen in its basket, ${ }^{1}$ and was in 1997 still on a de jure basket peg. All the others had been on intermediate regimes both de facto and de jure. Mexico, Indonesia, Russia, Brazil, and Turkey had all been keeping their exchange rates within target zones (bands), often combined with a preannounced rate of crawl. The Market Average Rate system of the Republic of Korea (Korea) had been classified by the International Monetary Fund (IMF) as managed floating (and the US Treasury semiannual reports to Congress had in the early 1990s pronounced that the Korean Government had stopped "manipulating" the value of the won, by which it meant that Korea had supposedly begun to let the private market determine the exchange rate $)^{2}$. These arrangements are neither fixed nor floating, but are properly denoted "intermediate regimes."

Accordingly, a second school of thought holds that it is precisely the looseness of the commitment that gets the intermediate regimes into trouble, and that the prescribed policy is a firm institutional commitment such as a currency board or the outright abolition of the national currency, in order to buy absolute credibility for the central bank. Examples include the currency boards of Hong Kong, China; Argentina (until 2001); and some other small economies, particularly in Eastern Europe (Estonia, Lithuania, Bulgaria); the dollarizers, old (Panama) as well as new (Ecuador, El Salvador, Guatemala); and the 12 members of the European Monetary Union (EMU). Proponents urge the virtues of currency boards or dollarization on emerging market countries everywhere.

The dominant conventional wisdom to emerge in the late 1990s was a third school of thought: the corners hypothesis. This viewpoint is also variously called bipolarity, hollowing out, the missing middle, and the hypothesis of the vanishing intermediate regime. It neither insists that countries generally should float nor that countries generally should institutionally fix. Rather, it says that countries generally should be (or are) moving to one extreme or the other, that the lesson of the recent crises is just the nonviability of intermediate regimes such as those followed in the crisis countries of the 1990s. Part IV of this paper discusses the corners hypothesis in more detail. It argues that the hypothesis may start to drop out of favor in the aftermath of the experiences of Argentina in 2001 and Brazil in 2002, as rapidly as it gained favor in the aftermath of the 1997-1998 East Asia crisis.

Although newspaper opinion/editorial pieces often pretend that there is only one valid side to an argument, economists are accustomed to thinking of everything as a trade-off between competing advantages. It is important not to rush to a judgment over the optimal exchange rate regime before listing pros and cons and then trying to add them up. The author's position is that all three categories of exchange rate regime - floating, firm fixing, and intermediate regimes - are appropriate for some countries, and that the choice of appropriate regime cannot be made independently of knowledge of the

\footnotetext{
1 Frankel $(1995 a, b)$ and Frankel and Wei $(1994,1997)$ offered statistical evidence against what was then the common view regarding links to the yen. More recent estimates of the implicit weights in the currency baskets of East Asian countries are offered by Benassy-Quere (1999) and Ohno (1999).

${ }^{2}$ Frankel (1993a, b).
} 
circumstances facing the country in question. No single regime is right for all countries, and even for a given country, it may be that no single regime is right at all times. ${ }^{3}$

After part I of this paper enumerates alternative exchange rate regimes, part II briefly reviews the advantages of fixed exchange rates, followed by the advantages of floating exchange rates. Part III discusses frameworks for tallying up the advantages on one side versus the other so that individual countries can make a decision; the traditional framework is the theory of optimum currency areas, but new lessons came out of the experience of the 1990s. Part IV discusses the rise (and possible fall) of the corners hypothesis. Part V reviews some empirical evidence on the performance of alternative regimes. Part VI surveys other possible nominal anchors, recognizing that for monetary authorities not to target the exchange rate opens the question of whether they should instead target something else, like the consumer price index (CPI), money supply, nominal gross domestic product (GDP), price of gold, or (a newly proposed contender for countries with specialized trade) the price of the export good. Part VII draws some implications for East Asia and the possibility of a common peg.

\section{Classifying Countries into Regimes}

There are of course many more regimes than two, an entire continuum that can be arrayed from most flexible to most rigidly fixed. I distinguish nine, grouped into the three broad categories of floating, intermediate, and firmly fixed. The list follows.
A. Floating corner
1. Free floating
2. Managed floating
B. Intermediate regimes
3. Band

3a. Bergsten-Williamson target zone (fundamental equilibrium exchange rate)

3b. Krugman-ERM target zone (fixed nominal central parity)

4. Crawling peg

4a. Indexed

4b. Preannounced crawl (tablita, in Spanish)

5. $\quad$ Basket peg

6. Adjustable peg

C. $\quad$ Firm fix corner

7. Currency board

8. Dollarization (or euro-ization)

9. Monetary union

There are many complications. Each of the intermediate regimes can itself range from so flexible as to belong truly in the floating category, to so rigid as to belong truly to the fixed corner. The relevant parameter in the case of the target zone is the width of the

\footnotetext{
${ }^{3}$ This position, while hardly momentous or novel, is the point made in Frankel (1999).
} 
margins. In the case of the crawl, it is the speed of crawl; in the case of the basket, it is the number of currencies in the basket and the extent to which the weights are publicly announced; and in the case of the adjustable peg, it is the magnitude of the shock necessary to trigger the change in the parity (the frequency of the contingency in a formally modeled "escape clause").

In addition, the target zone and the crawl each have two prominent subclassifications: one-deserving to be considered more flexible - in which the parity is adjusted in line with ex post inflation; and one in which it is not, in order to retain some of the benefits of a nominal anchor. To complicate things still further, the features of regimes 3-6 are not mutually exclusive, but rather are regularly mixed and matched. In the language of Williamson (1996, 1999, 2001), basket-band-crawl constitutes a single regime, abbreviated BBC. Nevertheless, I have chosen to list them as four separate regimes in the rough descending order of what seems to me their usual degree of flexibility.

It is worth being specific about the boundary separating categories $\mathrm{A}$ and $\mathrm{B}$, and that separating categories $\mathrm{B}$ and $\mathrm{C}$. The best classification scheme would define any managed floats as intermediate regimes (category B) if and only if there is an explicit target around which the central bank intervenes. Countries where the central bank intervenes in the foreign exchange market occasionally, but without any announced target, must be classified as floating; otherwise there will be no actual countries in the latter category. Toward the other end of the spectrum, a commitment to a fixed exchange rate should be classified in category $\mathrm{C}$, firm fix, rather than category $\mathrm{B}$, if and only if it goes beyond a declared policy to an institutional commitment (e.g., a law mandating a currency board that requires a parliamentary supermajority to reverse it).

\section{De facto regimes differ from de jure}

Placing actual countries into these categories is far more difficult than one who has never tried it would guess. One reason is that there is a substantial difference between de jure classifications and de facto classifications, between what countries say they do and what they actually do.

Most of those listed as floating in fact intervene in the foreign exchange market frequently. As Calvo and Reinhart (2000) and Reinhart (2000) correctly observe, "Countries that say they allow their exchange rate to float mostly do not." Only the United States (US) floats so purely that intervention is relatively rare.

At the other end of the spectrum, most of those classified as pegged have in fact had realignments within the last 10 years. Obstfeld and Rogoff (1995) report that as of 1995 only six major economies with open capital markets, in addition to a number of very small economies, had maintained a fixed exchange rate for 5 years or longer. Klein and Marion (1997) report that the mean duration of pegs among Western hemisphere countries is about 10 months. The implication is that conventional pegs should be called "adjustable pegs," and classified as intermediate regimes. 
Other methodologies have been suggested to classify countries in terms of the regimes that they actually follow, for example, by observing the variability in exchange rates and in reserve levels. ${ }^{4}$ Typically, however, the classification does not feel persuasive or definitive. Worryingly, the attempts at de facto classification differ widely, not just from the de jure classification, but from each other as well. ${ }^{5}$

\section{Trends in popularity of regimes}

We begin by considering the regimes currently followed by countries, as reported in the classification system of the International Monetary Fund's (IMF's) International Financial Statistics. This system does not follow countries' self-description as slavishly as it once did, but it is useful to keep in mind that it is nevertheless an official or de jure classification.

Forty-eight countries have altogether given up an independent currency, by means of a firm institutional fix; 12 are the members of European Monetary Union (EMU), and 36 are developing countries or transition economies. Of those 36 countries,

- 8 are "dollarized" (Ecuador, El Salvador, Panama, four South Pacific island countries, and San Marino where the legal tender is not the dollar but the Italian lira),

- 20 are in monetary unions (6 in the Eastern Caribbean Currency Union and 14 in the CFA franc zone ${ }^{6}$, and

- 8 are in currency boards (now 7, with the departure of Argentina).

Of the 36 firm-fixers among developing countries, only Ecuador and El Salvador have given up national currencies recently. The others never had independent currencies in the first place. (Guatemala is also apparently on the path to dollarization.) True, five sovereign countries in the 1990s adopted currency boards that they still have: Estonia (1992); Lithuania (1994); Bulgaria (1997); and Bosnia (1998); ${ }^{7}$ plus Hong Kong, China (1983). If one includes the EMU 12, that adds up to about 20 countries that have chosen ultra-fixed exchange rate arrangements in the past decade. Does this constitute evidence that the heralded world trend toward a smaller number of currencies has begun? I will argue that it does not.

Ninety-eight members of the IMF are classified in an intermediate regime. Of these 98 countries, 29 follow conventional fixed peg arrangements, and 10 follow basket

\footnotetext{
${ }^{4}$ Such as Calvo and Reinhart (2000) or Levy-Yeyati and Sturzenegger (2001).

5 The latest, Reinhart and Rogoff (2002) proposes two new categories, "freely falling" and dual exchange rates. This classification makes a big difference for the set of countries that remains behind in the traditional categories. (We return to the question of de facto classification schemes, and the lack of correlation among them, toward the end of the paper.)

${ }^{6}$ CFA = Communauté Financière de l'Afrique. Even the francophone countries of Africa finally devalued against the French franc in 1994, though they have retained their currency union among themselves.

7 Two smaller countries, Brunei Darussalam and Djibouti, have had currency boards since independence. In addition to these sovereign countries are some even smaller Caribbean island dependencies, Democratic Republic of Timor Leste, and Montenegro, which is said to be adopting a currency board too, or even declaring euros legal tender.
} 
pegs. Both categories include some that claim as their regime managed floating while exhibiting de facto pegs, but both categories should also be called "adjustable pegs." Sixteen follow bands or crawls (including five horizontal bands-four of them developing countries and one, Denmark, a remnant of the European Monetary System; four crawling pegs; and seven crawling bands). Forty-three are classified by the IMF as "managed floating with no preannounced path for the exchange rate," a category that may sound like a float but which typically entails sufficient de facto targeting and intervention that it should probably be classified as an intermediate regime.

That leaves 40 countries that the IMF classifies as independently floating. Of these, 9 are industrialized countries and 31 are developing, middle-income, or transition countries. Thus, excluding industrialized countries, 36 can be counted as in the firm fix corner, 98 classified as intermediate regimes, and 31 assigned to the floating corner. (Since this compilation, two South American countries in early 2002 adopted some sort of float, that cannot yet be characterized: Argentina, which left its currency board, and Venezuela, which previously had a crawling band. For purposes of the three-way classification, I will treat Argentina as trading places with Guatemala, and Venezuela as remaining in the intermediate category.)

There is a clear trend toward increased flexibility over the last 30 years. Some claim that a trend from the intermediate regimes toward floating has its counterpart in another trend from the intermediate regimes toward firm fixing. This is the claim that the middle is hollowing out. It sometimes leads to the claim that there will be fewer currencies in the future than in the past. Fischer (2001), for example, reports that between 1991 and 1999, the fraction of IMF members that followed intermediate regimes dropped from $62 \%$ (98 countries) to $34 \%$ (63 countries). The fraction with hard pegs rose from $16 \%(25)$ to $24 \%$ (45), while the fraction floating rose from $23 \%$ (36) to $42 \%(77)$.

There is nothing wrong with the Fischer statistics; expressing regime popularity in terms of percentages of IMF membership is probably the relevant metric from the viewpoint of the management of the organization. But it neglects that the membership of the IMF, or of just about any other list of the world's sovereign nations, has been expanding over time. During the same two decades, when roughly two dozen countries gave up monetary independence by adopting currency boards, dollarization, or EMU, roughly the same number of new countries has been created, mainly by the breakup of the Soviet Union. Each of these previously had shared its currency with neighbors. For this reason, out of the list of regions that are today's sovereign countries, roughly the same number share the currency of another today as they did 20 years ago.

Thus, only two developing countries that had their own sovereign currencies 10 or 20 years ago have given them up today (Ecuador and El Salvador), and only one more has adopted a currency board (Bulgaria). So much for the famous trend toward the firm fix corner! By this criterion, contrary to widespread impression, the facts do not support the claim that developing countries are rapidly moving toward the corners and vacating the middle.

One might instead assert a sort of Markov stasis, in which independent currencies are always being created, disappearing, and switching among regimes, but the overall 
pool remains roughly steady. Masson (2001) statistically rejects the hypothesis that "hard fix" and "hard float" are absorbing states, thus concluding empirically that intermediate regimes are not in fact vanishing.

\section{Advantages of Fixed Exchange Rates Versus Floating}

The starting point in an evaluation of fixed versus floating exchange rates should be a listing of the advantages of each. We consider here four advantages of fixing: providing a nominal anchor to monetary policy, encouraging trade and investment, precluding competitive depreciation, and avoiding speculative bubbles. We then consider four advantages of floating: giving independence to monetary policy, allowing automatic adjustment to trade shocks, retaining seigniorage and lender-of-last-resort capability, and avoiding speculative attacks.

\section{Advantages of fixed exchange rates}

Of the four advantages of fixed exchange rates, academic economists tend to focus most on the nominal anchor for monetary policy. The argument is that there can be an inflationary bias when monetary policy is set with full discretion. A central bank that wants to fight inflation can commit more credibly by fixing the exchange rate, or even giving up its currency altogether. Workers, firm managers, and others who set wages and prices then perceive that inflation will be low in the future because the currency peg will prevent the central bank from expanding even if it wanted to. When workers and firm managers have low expectations of inflation, they set their wages and prices accordingly. The result is that the country is able to attain a lower level of inflation for any given level of output. The nominal anchor argument, of course, presupposes that one is pegging to a hard currency, one that exhibits strong monetary discipline, like the deutsche mark. After the breakup of the Soviet Union, most of the 15 newly independent states wisely reached the judgment that the Russian rouble did not offer a good nominal anchor. The strength of the argument for basing monetary policy on an exchange rate target will also depend on what alternative nominal anchors might be available; this topic will be explored in part VI.

Thirty years ago, the argument most often made against floating currencies was the second one on the list: higher exchange rate variability would create uncertainty; this risk would in turn discourage international trade and investment. Fixing the exchange rate in terms of a large neighbor would eliminate exchange rate risk, and so encourage international trade and investment. Going one step farther, and actually adopting the neighbor's currency as one's own, would eliminate transactions costs as well and thus promote trade and investment still more.

Over most of the last few decades, academic economists have been skeptical of this claim, for three reasons. First, in theory, exchange rate uncertainty is merely the symptom of variability in economic fundamentals, so that if it is suppressed in the foreign exchange market, it will show up somewhere else, e.g., in the variability of the price level. Second, logically, anyone adversely affected by exchange rate variability- 
importers, exporters, borrowers, and lenders - can hedge away the risk, using forward markets. Third, empirically, it was hard to discern an adverse statistical effect from increased exchange rate volatility on trade. But each of these arguments can be rebutted. First, most exchange rate volatility in fact appears to be unrelated to macroeconomic fundamentals. Second, many developing country currencies have no forward markets; and even in those that do, there are costs to hedging (transactions costs plus the exchange risk premium). Third, more recent econometric studies, based on large cross sections that include many small and developing countries, have found stronger evidence of an effect of exchange rate variability on trade (especially on a bilateral basis, where far more data are available $)^{8}$ than did earlier studies. Table 1 reports estimates of the stimulus to trade and growth that individual developing countries would eventually experience if they were to adopt the dollar or the euro as their currencies.

\section{[Table 1 goes about here]}

A third advantage of fixed exchange rates is that they prevent competitive depreciation or competitive appreciation. Competitive depreciation can be viewed as an inferior Nash noncooperative equilibrium, where each country tries in vain to win a trade advantage over its neighbors. In such a model, fixing exchange rates can be an efficient institution for achieving the cooperative solution. The architects of the Bretton Woods system thought about the problem in terms of the "beggar thy neighbor" policies of the 1930s. The example can be updated by one possible interpretation of the notorious contagion experienced in the crises of the 1990s. Each time one country in East Asia or Latin America devalued, its neighbors were instantly put at a competitive disadvantage, serving to transfer the balance of payments pressure to them (e.g., from Mexico to Argentina in 1995, from Thailand to the rest of East Asia in 1997, and from Brazil to the rest of South America in 1999). Many of them felt that the standard prescription to devalue did not work, in an environment where their neighbors and competitors were devaluing at the same time. If so, a cooperative agreement not to devalue might seem called for.

The final argument for fixed exchange rates is to preclude speculative bubbles of the sort that pushed up the dollar in 1985 or the yen in 1995. As we already noted, some exchange rate fluctuations appear utterly unrelated to economic fundamentals. This observation then allows at least the possibility that, if the exchange rate fluctuations were eliminated, there might in fact not be an outburst of fundamental uncertainty somewhere else. Rather, the "bubble term in the differential equation" might simply disappear.

\section{Advantages of floating exchange rates}

As there are four advantages to fixed exchange rates, there are also four advantages to flexible exchange rates.

The leading advantage of exchange rate flexibility is that it allows the country to pursue an independent monetary policy. The argument in favor of monetary

${ }^{8}$ Frankel and Wei (1994), Rose (2000), Frankel and Rose (2002), and Parsley and Wei (2001). 
independence, instead of constraining monetary policy by the fixed exchange rate, is the classic argument for discretion, instead of rules. When the economy is hit by a disturbance, such as a fall in demand for the goods it produces, the government would like to be able to respond so that the country does not go into recession. Under fixed exchange rates, monetary policy is always diverted, at least to some extent, to dealing with the balance of payments. This single instrument can not be used to achieve both internal balance and external balance. Under the combination of fixed exchange rates and complete integration of financial markets, which for example characterizes EMU, the situation is more extreme: monetary policy becomes altogether powerless to affect internal balance. Under these conditions, the domestic interest rate is tied to the foreign interest rate. An expansion in the money supply has no effect: the new money flows out of the country via a balance-of-payments deficit, just as quickly as it is created. In the face of an adverse disturbance, the country must simply live with the effects. After a fall in demand, the recession may last until wages and prices are bid down, or until some other automatic mechanism of adjustment takes hold, which may be a long time. By freeing up the currency to float, on the other hand, the country can respond to a recession by means of monetary expansion and depreciation of the currency. This stimulates the demand for domestic products and returns the economy to desired levels of employment and output more rapidly than would be the case under the automatic mechanisms of adjustment on which a fixed-rate country must rely.

The unfortunate reality is that few developing countries have been able to make effective use of discretionary monetary policy. But even if one gives up on deliberate changes in monetary policy, there is a second advantage of floating: that it allows automatic adjustment to trade shocks. The currency responds to adverse developments in the country's export markets or other shifts in the terms of trade by depreciating, thus achieving the necessary real depreciation even in the presence of sticky prices or wages.

The third advantage of an independent currency is that the government retains two important advantages of an independent central bank: seigniorage and lender-of-lastresort ability. The central bank's ability to act as a lender of last resort for the banking system depends to a degree on the knowledge that it can create as much money as necessary to bail out banks in difficulty. For a while it was claimed that a country that moved to the firm-fix corner and allowed foreign banks to operate inside its borders, like Argentina, would not need a lender of last resort because the foreign parents of local banking subsidiaries would bail them out in time of difficulty. Unfortunately, Argentina's experience in 2001 has now disproved this claim.

Recall that the fourth argument for stabilizing the exchange rate arose from an increasingly evident disadvantage of free floating: occasional speculative bubbles (possibly rational, possibly not) that eventually burst. However, there is a corresponding fourth argument for flexibility that arises from an increasingly evident disadvantage of pegging: a tendency toward borrowers' effectively unhedged exposure in foreign currency (possibly rational, possibly not ${ }^{9}$ ), ending badly in speculative attacks and

\footnotetext{
${ }^{9}$ Some who have recently argued for floating on these grounds imply that it would be beneficial to introduce gratuitous volatility into the exchange rate to discourage unhedged borrowing in foreign currency.
} 
multiple equilibrium. Overvaluation, excessive volatility, and crashes are possible in either regime.

Frameworks for Tallying up the Advantages

Which factors are likely to dominate, the advantages of fixed exchange rates or the advantages of floating? There is not one right answer for all countries. The answer must depend, in large part, on the characteristics of the country in question. One example of an important criterion is the origin of economic disturbances. If the country is subject to many external disturbances, such as fluctuations in foreigners' eagerness to buy domestic goods and domestic assets (perhaps arising from business cycle fluctuations among the country's neighbors), then it is more likely to want to float its currency. In this way, it can insulate itself from the foreign disturbances, to some degree. On the other hand, if the country is subject to many internal disturbances, then it is more likely to want to peg its currency.

Definition of Optimum Currency Area

Many of the country characteristics that are most important to the fixed-versus-floating question are closely related to the size and openness of the country. This observation brings us to the theory of the optimum currency area (OCA). ${ }^{10}$

Countries that are highly integrated with each other with respect to trade and other economic relationships are more likely to constitute an OCA. An OCA is a region for which it is optimal to have its own currency and its own monetary policy. This definition, though in common use, may be too broad to be of optimum utility. It can be given some more content by asserting the generalization that smaller units tend to be more open and integrated with their neighbors than larger units. Then an OCA can be defined as a region that is neither so small and open that it would be better-off pegging its currency to a neighbor, nor so large that it would be better-off splitting into subregions with different currencies. Even to the extent that corner solutions are appropriate for given countries, the optimal geographic coverage for a common currency is likely to be intermediate in size: larger than a city and smaller than the entire planet.

\section{The Traditional OCA Criteria}

Why do the OCA criteria depend on integration? The advantages of fixed exchange rates increase with the degree of economic integration, while the advantages of flexible exchange rates diminish. This is clearest when integration is defined as openness to trade, but is also true for other sorts of integration.

Openness. Recall the two big advantages of fixing the exchange rate that we identified earlier: (i) to reduce transactions costs and exchange rate risk that can discourage trade and investment, and (ii) to provide a credible nominal anchor for monetary policy. If traded goods constitute a large proportion of the economy, then exchange rate uncertainty

10 The issues are surveyed by Tavlas (1992), and also reviewed by Bayoumi and Eichengreen (1994). 
is a more serious issue for the country in the aggregate. ${ }^{11}$ Such an economy may be too small and too open to have an independently floating currency.

Labor mobility. One OCA criterion offered in the original Mundell (1961) article was labor mobility, here defined as the ease of labor movement between the country in question and its neighbors. If the economy is highly integrated with its neighbors by this criterion, then workers may be able to respond to a local recession by moving across the border to get jobs, so there is less need for a local monetary expansion or devaluation.

Fiscal cushions. The existence of a federal fiscal system to transfer funds to regions that suffer adverse shocks offers another way to help mitigate macroeconomic fluctuations in the absence of an independent currency.

Symmetry. To the extent that shocks to the two economies are correlated, monetary independence is not needed in any case: the two can share a monetary expansion in tandem.

Political willingness to accept neighbors' policies To the extent that domestic residents have economic priorities - especially on fighting inflation versus unemployment - that are similar to those of their neighbors, there will be less need for a differentiated response to common shocks.

\section{Criteria of the $1990 \mathrm{~s}$}

The introduction of currency board-like arrangements in Hong Kong, China (1983); Argentina (1991); Estonia (1992); Lithuania (1994); Bulgaria (1997); Bosnia (1998); and two smaller countries constituted a resurgence in their use worldwide. A currency board can help to create a credible policy environment by removing from the monetary authorities the option of printing money to finance government deficits. Argentina, for example, at first benefited from such credibility. Argentina was prompted to adopt a currency board (which it called the convertibility plan) because of a dramatic hyperinflation in the 1980s and the absence of a credible monetary authority. After 1991, Argentina became a model of price stability and achieved laudable growth rates, aside from setbacks such as the Mexican peso "tequila"-induced recession in 1995, from which Argentina soon rebounded strongly. By most accounts, the currency board was working for Argentina.

And yet Argentina never did fit well the traditional OCA criteria. It is not particularly small or open, or subject to high labor mobility or close correlation with the US economy. A new set of criteria to supplement or even replace the OCA framework were proposed, relevant particularly to the decision to adopt an institutional commitment to a fixed rate. Whereas the older framework had to do with trade and cyclical stability, the new characteristics had to do with international financial markets and credibility. The additional criteria $^{12}$ follow:

${ }^{11}$ This is the rationale for the openness criterion originally suggested by McKinnon (1963).

${ }^{12}$ Similar lists are also offered by Williamson (1996) and Larrain and Velasco (2001). 
- a strong (even desperate) need to import monetary stability, due to either a history of hyperinflation, an absence of credible public institutions, unusually large exposure to nervous international investors, or instability arising from a dangerous political environment;

- a desire for further close integration with a particular neighbor or trading partner (which has the added advantage of enhancing the political credibility of the commitment);

- $\quad$ an economy in which the foreign currency is already widely used; ${ }^{13}$

- access to an adequate level of reserves;

- rule of law; and

- a strong, well-supervised, and regulated financial system.

Currency board supporters pushed for its wider use in the crises of the 1990s-in particular, for Indonesia, Russia, and Ukraine. Proclaiming a currency board does not automatically guarantee the credibility of the fixed rate peg. Little credibility is gained from putting an exchange rate peg into the law, in a country where laws are not heeded or are changed at will. Beyond the rule of law, a currency board is unlikely to be successful without the solid fundamentals of adequate reserves, fiscal discipline, and a strong and well-supervised financial system.

\section{The Rise and fall of the Corners Hypothesis}

The debate over exchange rate regimes is an old one. And yet, a genuinely new element was thrown into the mix in the late 1990s. This is the proposition that countries are-or should be-moving to the corner solutions. They are said to be opting either, on the one hand, for full flexibility, or, on the other hand, for rigid institutional commitments to fixed exchange rates, in the form of currency boards or full monetary union with the dollar or euro. It is said that the intermediate exchange rate regimes are no longer feasible. The target zones, crawls, basket pegs, and pegs-adjustable-under-an-implicitescape-clause are going the way of the dinosaurs. A corollary of this theory is that the number of independent currencies in the world is declining, perhaps with a rising fraction of the world accounted for by a few large regional blocs built around the dollar, the euro, and perhaps the yen or some other currency in Asia.

\footnotetext{
${ }^{13}$ In a country that is already partially dollarized, devaluation is of little use. If many wages and prices are already tied to the dollar, they will simply rise by the same amount as the exchange rate. If liabilities are already denominated in dollars-and, in the case of international liabilities, foreign creditors in emerging markets generally insist on this-then devaluation may bankrupt domestic borrowers. Such initial conditions are discussed as criteria for dollarization by Calvo (1999) and Hausmann et al. (1999).
} 
Surely a proposition that has become such conventional wisdom as the vanishing intermediate regime has a distinguished intellectual pedigree? Not really.

\section{Intellectual origins}

What is known about the origins of the hypothesis of the vanishing intermediate regime? Is it new? A sixteenth century proverb says, "There is nothing new under the sun."14 A precursor for the corners hypothesis is Friedman (1953, p.164): "In short, the system of occasional changes in temporarily rigid exchange rates seems to me the worst of two worlds: it provides neither the stability of expectations that a genuinely rigid and stable exchange rate could provide in a world of unrestricted trade...nor the continuous sensitivity of a flexible exchange rate." Yet the pure corners hypothesis is more recent than that; such intermediate regimes as target zones did not become popular until the 1980s and 1990s. The earliest known explicit reference to the corners hypothesis is by Eichengreen (1994). The context was not emerging markets, but rather the European exchange rate mechanism (ERM). In the ERM crisis of 1992-1993, Italy, the United Kingdom, and others were forced to devalue or drop out altogether, and the bands had been subsequently widened substantially so that France could stay in. This crisis suggested to some that the strategy that had been planned previously - a gradual transition to the EMU, where the width of the target zone was narrowed in a few stepsmight not be the best way to proceed after all. Crockett (1994) made the same point. Obstfeld and Rogoff (1995) concluded, "A careful examination of the genesis of speculative attacks suggests that even broad-band systems in the current EMS style pose difficulties, and that there is little, if any, comfortable middle ground between floating rates and the adoption by countries of a common currency." The lesson that "the best way to cross a chasm is in a single jump" was seemingly borne out subsequently, when the leap from wide bands to EMU proved successful in 1998-1999.

After the East Asia crises of 1997-1998, the hypothesis of the vanishing intermediate regime was applied to emerging markets. In the effort to "reform the financial architecture" so as to minimize the frequency and severity of crises in the future, the proposition was rapidly adopted by the financial establishment as the new conventional wisdom.

For example, Summers (1999a):

"There is no single answer, but in light of recent experience what is perhaps becoming increasingly clear-and will probably be increasingly reflected in the advice that the international community offers - is that in a world of freely flowing capital there is shrinking scope for countries to occupy the middle ground of fixed but adjustable pegs. As we go forward from the events of the past eighteen months, I expect that countries will be increasingly wary about committing themselves to fixed exchange rates, whatever the temptations these may offer in the short run, unless they are also prepared to dedicate policy

\footnotetext{
${ }^{14}$ The proverb is based on Ecclesiastes, Ch. 1, v. 9: “...there is no new thing under the sun."
} 
wholeheartedly to their support and establish extra-ordinary domestic safeguards to keep them in place."

Other high-profile examples include Eichengreen (1999, p.104-105), Minton-Beddoes (1999), and Council on Foreign Relations (1999, p.87). The G-7 (Group of Seven) Finance Ministers agreed that the IMF should not in the future bail out countries that get into trouble by following an intermediate regime, though it qualified the scope of the generalization a bit, for example, by allowing a possible exception for "systemically" important countries.

It is not only the international financial establishment that has decided intermediate regimes are nonviable. The Meltzer report, commissioned by the US Congress to recommend fundamental reform of international financial institutions, adopted the proposition as well: "The Commission recommends that ...the IMF should use its policy consultations to recommend either firmly fixed rates (currency board, dollarization) or fluctuating rates" (Meltzer 2000, p.8).

The Economist (1999, p.15-16) was thus probably right when it wrote that "Most academics now believe that only radical solutions will work: either currencies must float freely, or they must be tightly tied (through a currency board or, even better, currency unions)." But the proposition remains yet to be demonstrated.

It is true that for the middle-income emerging market countries, all of which have been exposed to substantial financial volatility in recent years, the casualties among intermediate regimes have been high. Mexico, Thailand, Korea, Indonesia, Russia, Brazil, and Turkey were each forced by speculative attack to abandon a sort of basket or band. The other countries that abandoned band arrangements in the late 1990s also included the Czech Republic (27 May 1997), Ecuador (4 March 1999), Chile (3 September 1999), and Colombia (26 September 1999). ${ }^{15}$ While most of these policy changes took place under great pressure, Chile was not facing tremendous speculative pressure when it made its switch. Indonesia abandoned the bands before the full crisis hit. This move won praise at the time. Even though the country was soon thereafter hit with the worst of the Asian crises, commentators today tend to include Indonesia in the list of data points that is supposed to demonstrate the superiority of the floating option over the band option.

At the same time, Hong Kong, China, in Asia and Argentina in Latin America, the two economies with currency boards, were the ones that got through the 1990s successfully, judged by the (very particular) criterion of avoiding being forced into increased exchange rate flexibility. As a statement of observed trends, at least, the set of emerging market countries in the late 1990s did seem to bear out the claimed movement toward the corners. It seems intuitively right that these countries, facing finicky international investors and rapidly disappearing foreign exchange reserves, had little alternative but to abandon their pegs and baskets and bands and crawls and move to a float, unless they were prepared to go to the opposite corner. But this proposition is in need of a rationale.

\footnotetext{
${ }^{15}$ Goldman Sachs.
} 
Should countries be moving toward the corners? We saw in part II that a majority of developing countries still follow intermediate regimes. Do they have good reasons for their choices? Close to the center of the economists' creed is that interior solutions are more likely to be optimal-for the interesting questions-compared with corner solutions.

\section{Lack of theoretical foundations for the corners hypothesis}

What is the analytical rationale for the hypothesis of the disappearing intermediate regime (or the "missing middle")? Surprisingly, none currently exists.

At first glance, it appears to be a corollary to the principle of the Impossible Trinity. ${ }^{16}$ That principle says that a country must give up one of three goals: exchange rate stability, monetary independence, and financial market integration. It cannot have all three simultaneously. If one adds the observation that financial markets are steadily becoming more and more integrated internationally, that forces the choice down to giving up on exchange rate stability or giving up on monetary independence.

This is not the same thing, however, as saying one cannot give up both complete stability and complete independence, that one cannot have half-stability and half-

not in

ref.

Supply bibliog raphic data independence in monetary policy. Economists tend to believe in interior solutions for most problems. In the closed-economy context, Rogoff (1985) derived the optimal intermediate degree of commitment to a nominal target for monetary policy, balancing the advantages of precommitment against the advantages of discretionary response to shocks.

There is nothing in existing theory, for example, that prevents a country from pursuing an exchange rate target zone of moderate width. The elegant line of target-zone theory begun by Krugman (1991), in which speculation helped stabilize the currency, always assumed perfect capital mobility. Similarly, there is nothing that prevents the government from pursuing a managed float in which half of every fluctuation in demand for its currency is accommodated by intervention and half is allowed to be reflected in the exchange rate. (To model this, one need only introduce a "leaning against the wind" central bank reaction function into a standard monetary model of exchange rate determination.) And there is nothing that prevents a country from pursuing a peg with an escape clause contingent on exogenous shocks or, more practically, a peg that is abandoned whenever there is a shock large enough to use up half its reserves.

Another justification that has been offered for the corners hypothesis is that when a government establishes any sort of exchange rate target, as did the East Asian countries, its banks and firms foolishly underestimate the possibility of a future break in the

\footnotetext{
${ }^{16}$ Summers (1999b, p. 326) is explicit: "...the core principle of monetary economics is a trilemma: that capital mobility, an independent monetary policy, and the maintenance of a fixed exchange rate objective are mutually incompatible. I suspect this means that as capital market integration increases, countries will be forced increasingly to more pure floating or more purely fixed exchange rate regimes."
} 
currency value. ${ }^{17}$ As a result, they incur large unhedged dollar liabilities abroad. When a devaluation occurs, their domestic-currency revenues are inadequate for servicing their debts, and so they go bankrupt, with devastating consequences for the economy.

"It follows that in a world of high capital mobility there are only two feasible approaches to exchange rate policy. One is not just to peg the exchange rate, but to lock it in - the Argentine strategy....The vast majority of countries will ... have to follow the other alternative of allowing their currencies to fluctuate. If the exchange rate moves regularly, banks and firms will have an incentive to hedge their foreign exposures..." (Eichengreen 1999, p.105).

There is little doubt that the focus on unhedged foreign-currency debt describes accurately how the 1997-1998 devaluations contributed to recessions in East Asia. But the argument, as stated, has some weaknesses. First, it appears to depend on irrationality on the part of banks and firms. Second, it appears to imply that a country would be betteroff by gratuitously introducing extra noise into the exchange rate, to deter borrowers from incurring unhedged dollar liabilities. This seems unlikely to be right. Third is the point emphasized by Ricardo Hausmann: foreigners are unwilling to take open positions in the currencies of emerging-market countries. ${ }^{18}$ Thus the admonition to avoid borrowing in dollars is to some extent an admonition to avoid borrowing at all. It may well be that this is the right road to go down, that exchange rate volatility is a way to put some sand in the wheels of the excessive capital movements, and that a lower volume of total debt is a good outcome. But if this is the argument, the proponents should be explicit about it. In any case, it seems doubtful that this argument could be captured by conventional models. Recall that Tobin's original motivation for proposing to put sand in the wheels of international capital movement was to reduce exchange rate volatility!

A third possible justification is that governments that adopt an exchange rate target, and sometime later experience a major reversal of capital inflows, tend to wait too long before abandoning the target. As of 1998, we thought we had learned that the one thing an emerging-market government can do to minimize the eventual pain from a currency crisis is to try to devalue early enough (or else raise interest rates early enough, as would happen automatically under a currency board - anything to adjust, rather than try to finance an ongoing deficit). Mexico, Thailand, and Korea made the mistake of waiting too long until reserves ran very low, so that by the time of the devaluation there was no good way out, no combination of interest rates and exchange rate that would simultaneously satisfy the financing constraint externally and prevent recession domestically. But exiting from an exchange rate target can be difficult politically. The lesson is drawn that, to avoid this difficulty, governments should either adopt a rigid

\footnotetext{
17 The version of this argument in Eichengreen (1999, p.104) overstates the extent to which the East Asians had "a stated commitment to the peg," as most commentators have done as well. In fact, as already noted, few of the East Asian countries had explicit dollar pegs.

${ }^{18} \mathrm{He}$ calls this the "original sin." The term is not meant to imply that the fault lies in policy failings of the local government. An admonition to hedge the dollar exposure is not helpful; someone has to take the other side of the futures contract, and this will be difficult in the aggregate if foreigners are unwilling to take the open position.
} 
institutional fixed-rate commitment (as did Ecuador) or, if not prepared to do that, abandon the peg early. ${ }^{19}$

On this basis, when Brazil in the autumn of 1998 delayed the seemingly inevitable jettisoning of the exchange rate target that remained from its real plan, many thought this would be a repeat of the earlier mistakes. Instead, when the devaluation finally came in January 1999, Brazil's trade balance improved sharply, the lack of confidence subsided, and output and employment subsequently performed far better than in neighboring Argentina. Thus, it is more difficult to generalize from recent experience than widely believed. Furthermore, if we are to use government reluctance to exit a target arrangement as the basis of a model of the nonviability of intermediate regimes, it seems that we would again require some sort of irrationality (or political constraints ${ }^{20}$ ) on the part of policy makers.

Thus, each of the three arguments offered - the impossible trinity, the dangers of unhedged dollar liabilities, and the political difficulty of exiting-contains some important truth. But none seems able to stand as a theoretical rationale for the superiority of the corners solutions over the intermediate regimes. Perhaps the corners hypothesis, then, is just a misplaced manifestation of the temptation to believe that the grass is always greener somewhere else, in this case, in the corners of the pasture?

Frankel et al. (2000) offer another possible reason to favor the firm fix corner: verifiability. Central banks announce intermediate targets such as exchange rates so that the public can judge from observed data whether they are following the policy announced. The general point of that paper is that simple regimes are more verifiable by market participants than complicated ones. Of the various intermediate regimes (managed float, peg with escape clause, etc.), that paper focuses on basket pegs with bands. Statistically, it takes a surprisingly long span of data to distinguish such a regime from a floating exchange rate. We apply the econometrics, first, to the example of Chile and, second, by performing Monte Carlo simulations. The amount of data required to verify the declared regime may exceed the length of time during which the regime is maintained. The amount of information necessary increases with the complexity of the regime, including the width of the band and the number of currencies in the basket.

Although Frankel et al. (2000) may have convinced a few people that BBC regimes are not as verifiable as previously thought, it has not been accepted as a theoretical rationale for the corners hypothesis. The model to support the proposition is yet to be designed.

In the author's view, the Argentine crisis of 2001 dealt a severe blow to the conventional view that a country that was willing to make a firm and sincere institutional commitment to a rigidly fixed exchange rate, as under a currency board, could thereby

\footnotetext{
${ }^{19}$ Taipei,China, for example, devalued promptly in the Fall of 1997, and suffered less than the others. Chile and Israel are two other countries who are said to have "exited" successfully from exchange rate targets by doing so sufficiently early. But this has not always worked. When Indonesia in 1997 or Turkey in 2000 built in some extra flexibility, it did them little good.

${ }^{20}$ Governments may have an incentive to postpone devaluations until after elections. See Stein and Streb $(1998,1999)$.
} 
import credibility, and achieve convergence in price levels and interest rates. It has thereby also dealt a severe blow to the corners hypothesis. The situation is far worse than the remarkable fact that a supposedly ironclad fix came undone in a short period of time. Argentina's 1999-2002 recession has been so severe as to fully reverse the very good income gains during the heyday of the currency board, 1991-1998. If the average growth rates reported in the next section were updated, it seems likely that the entire currency board category would be pulled down substantially.

There will be those who will say that the events of 2001 merely prove that Argentina did not go far enough, that it should have gone all the way to full dollarization. But the example of Ecuador is instructive. Three years after its move to full dollarization, inflation still exceeds $20 \%$. True, Ecuador devalued sharply before it decided to dollarize, so that much of the increase in the price level could be interpreted as catching up to purchasing power parity (PPP). But there are two disturbing points: (i) the process has taken 3 years, and inflation is still there; and (ii) apparently the currency is now overvalued in real terms. Many economists have lost their ability to be surprised by the realities of slow price adjustment, inertial inflation, and failures of PPP. Nevertheless, that such imperfections of the goods market can remain so severe in a dollarized economy means that the transforming benefits of dollarization (and the realism of a forward-looking expectations theory) have been greatly oversold. Furthermore, Ecuador's interest rates have not converged to US interest rates any better than did Argentina's interest rates in the 1990s.

Perhaps Ecuador is too small a country to serve as the basis of generalization. But it is now probably the largest of the developing countries to be in the institutionally fixed corner. To say that very small open economies must decide whether or not to give up their currencies is true. But the firm-fix zealots certainly had in mind something of general applicability, as did even the mainstream proponents of the corners hypothesis. That no moderate-size emerging market country has successfully adopted a currency board or dollarization must cast doubts on the strength of the alleged trend.

Meanwhile many developing countries, especially in East Asia, have quietly been moving back in the direction of de facto intermediate regimes. Malaysia has an exchange rate target (aided, at least initially in 1998, by capital controls). Even the star floaters, Mexico and Brazil, have started intervening in the foreign exchange market again. The latter country was under severe financial pressure at the time of writing (August 2002); the IMF responded with a new program that deliberately increased the central bank's ability to intervene in the foreign exchange market.

\section{Empirical evidence on the performance of regimes}

Because there are so many pros and cons to exchange rate regimes, there have been few attempts at an overall empirical evaluation of their performance. The estimates reported in Table 1 will not serve, for example, because they are designed to capture only one of many effects on growth (the stimulus that common currencies give to trade). They leave out the potential advantages of countercyclical stabilization under flexible exchange 
rates, or long-term price stability under fixed exchange rates. Here we review three recent attempts to evaluate overall performance that have received a lot of attention.

Ghosh et al. (2000) compared the economic performance of currency boards, other pegs, and floating exchange rates, with countries placed into regimes by the IMF's de jure classification system. The upper panel of Table 2 summarizes their finding with respect to the growth rate. The currency boards grew the most rapidly, on average, by a considerable margin. The average growth rates of the floaters and the regular pegs are fairly close together; which is higher depending on whether one looks at growth in total income or in income per capita. Long-term growth, of course, depends on many variables besides the exchange rate regime, such as size, lagged income, the investment rate, population growth, openness, and political stability. The authors control for such determinants in a regression and get similar results. Again currency boards perform the best, followed by floaters and then by noncurrency board pegs.

\section{[Table 2 about here]}

Levy-Yeyati and Sturzenegger (2002) go through a similar exercise, but with countries classified among regimes based on their de facto classification system explained earlier. They are interested in the three-way distinction float, fix, and intermediate, shown in the middle panel of Table 2. When they use the IMF's classification system, the intermediate regimes perform the best. But when they use their own de facto system (LYS), the ranking precisely reverses. Now the floaters grow the most rapidly. When they run regressions to condition growth rates on standard determinants, they get similar answers to the unconditional averages: according to the IMF classification, the intermediate regimes do the best, while according to the LYS classification, the intermediate regimes do the worse, and the floaters do the best.

As already mentioned, Reinhart and Rogoff (2002) suggest breaking out countries that have dual or multiple exchange rates, as a separate category. But for the average growth rates, it does not seem to make very much difference. Among the remaining categories, the ranking of the growth rates is almost the same as if one took the IMF classification without breaking out dual rates. Countries with limited flexibility come in first, and floaters come in last.

Three attempts, three different answers. The IMF classification says that intermediate regimes grow the fastest, the Ghosh et al (2000) classification claims that currency boards do, and the LYS classification assigns floaters that honor. The differences appear to have less to do with methodology (what is controlled for) or sample (time period or set of countries), than with the classification scheme with which each starts. Table 3 shows that the alternative de facto regime classification regimes that have been proposed are surprisingly uncorrelated with each other, quite aside from the correlation with de jure classification. This confirms that the distinctions among exchange rate regimes, which seem so clear-cut when building theories, turn out to be far messier in reality.

[Table 3 about here] 


\section{Other possible nominal anchors}

Many central banks would like to convince their citizens to expect no inflation. Without high expectations of inflation, workers will ask for lower wages, firms will accept lower prices, and investors will demand lower interest rates. As a consequence, the central bank can achieve any given level of output and employment with a low rate of money creation and inflation. The question is how to convince the public to lower its expectations of inflation. The day is past when it is enough for the central bank to proclaim its firm intention to pursue a low rate of money creation and inflation. Such announcements are not necessarily considered credible.

Governments can achieve credibility by tying their hands in some way so that in the future they cannot follow expansionary policies even if they want to. Otherwise, they may be tempted in a particular period (such as an election year) to reap the short-run gains from expansion, knowing that the major inflationary costs will not be borne until the future. A central bank that would like to constrain itself so that in the future it can resist the political pressures and economic temptations of expansion is like Odysseus in the Greek myth. As his ship was approaching the rocks from where the seductive sirens lured weak-willed sailors to their doom, Odysseus had his sailors tie him to the mast.

How can a central bank make a binding commitment to refrain from excessive money creation? It can tie its hands by a rule, a public commitment to fix a nominal magnitude. Possible candidates for nominally anchored monetary regimes include monetarism, a gold standard, inflation targeting, nominal income targeting, and exchange rate pegs. In each case, the central bank is deliberately constrained by a rule setting monetary policy so as to fix a particular magnitude - the price of gold, the money supply, the inflation rate, nominal income, or the exchange rate. Monetary policy is automatically tightened if the magnitude in question is in danger of rising above the pre-set target, and is automatically loosened if the magnitude is in danger of falling below the target. The goal of such nominal anchors is to guarantee price stability.

Preventing excessive money growth and inflation is the principal "pro" argument for fixing the price of gold or some other nominal anchor. What, then, are the "con" arguments? The overall argument against the rigid anchor is that a strict rule prevents monetary policy from changing in response to the needs of the economy. The general problem of mismatch between the constraints of the anchor and the needs of the economy can take three forms: (i) loss of monetary independence, (ii) loss of automatic adjustment to export shocks, and (iii) extraneous volatility. First, under a free-floating currency, a country has monetary independence. In a recession, when unemployment is temporarily high and real growth temporarily low, the central bank can respond by increasing money growth, lowering interest rates, depreciating the currency, and raising asset prices, all of which to mitigate the downturn. Under a pegged currency, however, the central bank loses that sort of freedom. It must let recessions run their course. The second point is that even if the central bank lacks the reflexes to pursue a timely discretionary monetary policy, under a floating exchange rate, a deterioration in the international market for a country's exports should lead to an automatic fall in the value of its currency. The resulting stimulus to production will mitigate the downturn even without any deliberate 
action by the government. Again, this mechanism is normally lost under a rigid nominal anchor.

A third consideration makes the problem still more difficult. If a country has rigidly linked its monetary policy to some nominal anchor, exogenous fluctuations in that anchor will create gratuitous fluctuations in the country's monetary conditions that may not be positively correlated with the needs of that particular economy.

Each of the various magnitudes that are candidates for nominal anchor has its own characteristic sort of extraneous fluctuations that can wreck havoc on a country's monetary system.

- Fixed exchange rate. Under a fixed exchange rate, fluctuations in the value of the particular currency to which the home country is pegged can produce needless volatility in the country's international price competitiveness. For example, the appreciation of the dollar from 1995 and 2001 was also an appreciation for whatever currencies were linked to the dollar. Regardless of the extent to which one considers the late-1990s dollar appreciation to have been based in the fundamentals of the US economy, there was no necessary connection to the fundamentals of smaller dollar-linked economies. The problem was particularly severe for some far-flung economies that had adopted currency boards over the preceding decade: Hong Kong, China; Argentina; and Lithuania.

- Monetarism. Under a rule that fixes the rate of growth of the money supply, fluctuations in the public's demand for money or in the behavior of the banking system can directly produce gratuitous fluctuations in the interest rate and thereby in the real economy. Such velocity shocks may be particularly large in developing countries undergoing financial liberalization. ${ }^{21}$

- Inflation targeting. The current fashion is targeting the price level or inflation rate. Inflation targeting was adopted in the early 1990s by such countries as Australia, Canada, Finland, New Zealand, Spain, Sweden, and United Kingdom . $^{22}$ After 1997, some important emerging market countries followed suit: Brazil, Chile, Czech Republic, Israel, Poland, and South Africa. East Asian countries that have moved in this direction include Indonesia, Korea, and Philippines. ${ }^{23}$ Relative to M1 targeting, a key advantage of inflation targeting is the offsetting of velocity shocks. But, as the proponents recognize, the inflation target may have to be abandoned in the face of large supply shocks, such as oil price increases facing an oil-importing country. The

\footnotetext{
21 E.g., Dekle and Pradhan (1997).

22 Among many possible references on inflation targeting generally are Svensson (1995), Bernanke et al (1999), and Loayza and Soto (2002).

${ }_{23}$ Proponents of the arrangement for developing countries include Mishkin (2000) and Debelle (2001). But Masson et al. (1997) argue that developing countries may not be well-suited to inflation targeting.
} 
alternative of continuing to set monetary policy so as to prevent a surge in the price level would imply a needlessly severe recession.

- Nominal income targeting. The need for robustness with respect to velocity shocks and import price shocks, respectively, is used to argue the superiority of nominal income targeting over money targeting and inflation targeting. ${ }^{24}$ But nominal income targeting, even as a proposal, has received less attention in recent years and most proponents have industrialized countries in mind rather than developing countries. On one hand, McKibbin and Singh (2000) argue that nominal income targeting is particularly appropriate for developing countries because they face large supply shocks. On the other hand, a practical argument against nominal income targeting that has been important for developing countries, at least in the past, is that the GDP data have often been available only with a delay of 1 or 2 years.

- Gold standard. If a country pegs the price of gold, the economy is hostage to the vagaries of the world gold market. For example, when much of the world was on the gold standard in the 19th century, global monetary conditions depended on the output of the world's gold mines. The system did not in fact guarantee price stability. ${ }^{25}$

- Commodity basket. One proposal is that monetary policy should target a diversified basket of basic mineral and agricultural commodities. The idea is that a broad-based commodity standard of this sort would not be subject to the vicissitudes of a single commodity such as gold. ${ }^{26}$ If the basket reflected the commodities produced and exported by the country in question, the proposal could work. But for a country that is a net importer of oil, wheat, and other mineral and agricultural commodities, such a peg gives precisely the wrong answer in a year when the prices of these commodities go up. Just when the domestic currency should be depreciating to accommodate an adverse movement in the terms of trade, it appreciates instead. In other words, a regime of pegging to a basket of commodities would be vulnerable to terms of trade shocks. Brazil should not peg to oil, Kuwait should not peg to wheat, and Korea should not peg to either.

- Export commodity standard. Frankel (2002) puts forward the idea of pegging the currency to the price of the export good. ${ }^{27}$ This proposal may sound

\footnotetext{
${ }^{24}$ E.g., Frankel (1995a) demonstrates the point mathematically and gives many other references on nominal income targeting. Frankel (1995b) applies to emerging market countries.

${ }^{25}$ Cooper (1985). Proponents reply that the sort of price stability that is most important for efficient long-term economic planning by individuals is not simply minimizing short-run variability, but rather the guarantee against large inflationary episodes that a gold standard is designed to offer.

${ }^{26}$ A "commodity standard" was proposed in the 1930s—by B. Graham (1937)—and subsequently discussed by F. Graham (1941), Keynes (1938), and others. It was revived in the 1980s as a less narrow version of proposals to return to a gold standard.
}

${ }^{27}$ Also Schleisser (2001) and Frankel and Saiki (2002). 
similar to inflation targeting. But inflation-targeters target the consumer price index (CPI). The main difference between the CPI and the export price is the terms of trade. When there is an adverse movement in the terms of trade, one would like the currency to depreciate, yet price level targeting can have the opposite effect. For example, positive oil shocks as in 1973, 1979, or 2000 would have required monetary tightening in an oil-importing country if the central bank had been constrained to hit an inflation target. The result can be sharp falls in national output. Thus under rigid inflation targeting, supply or terms-of-trade shocks can produce unnecessary and excessive fluctuations in the level of economic activity. But targeting the price of domestically produced goods is a possible solution. It would have the advantage of robustness with respect to import price shocks that a CPI target lacks, without the data problems of nominal income targeting. Papua New Guinea could peg to gold, Indonesia to oil, Chile to copper, Colombia to coffee, Argentina to wheat, and Korea to semiconductors. If these countries had been pegged to these commodities in the late 1990s - a time of weak export markets and curtailed availability of international finance-their currencies would have automatically depreciated and stimulated exports, at precisely the time when a boost to the balance of payments was needed.

To recap, each of the most popular variables that have been proposed as candidates for nominal anchors is subject to fluctuations that will add an element of unnecessary monetary volatility to a country that has pegged its money to that variable: velocity shocks in the case of M1, supply shocks in the case of inflation targeting, fluctuations in world gold markets in the case of the gold standard, terms of trade shocks in a commodity basket standard, and fluctuations in the anchor currency in the case of exchange rate pegs. A novel candidate for nominal anchor, the export price, bears consideration.

\section{Implications for East Asia}

Many Asian countries are reluctant to float freely. They crave a return to some measure of exchange rate stability. They range in the extent of their desire for stability, or in willingness to constrain their policies in order to achieve such stability. But even those who wish to peg-or maintain their peg, like Hong Kong, China-have a problem. To whom should they peg? The appreciation of the dollar against the yen and euro from 1995 to 2001 hurt countries pegged to the dollar, and is considered by some as a major cause of the crises of the late 1990s.

For Eastern European countries wishing to stabilize their exchange rate, the euro is the natural anchor currency. For most Latin American countries wishing to stabilize their exchange rate, the dollar is the natural anchor currency. This is less true for Argentina and Chile, who - in part due to geography - have a more diversified pattern of trade. For Asian countries wishing to stabilize their exchange rates, the choice of currency is much less clear. That so many countries in Asia got into trouble by linking to the dollar is no coincidence. (More precisely, the bad luck of an appreciating dollar in the second half of the 1990s, especially vis-a-vis the yen, explains the timing of the pressure 
on Asian countries. But the fact that the dollar had occupied a larger role in their monetary arrangements than the US played in their economies made an eventual mismatch inevitable. In this respect East Asia resembles Argentina and Lithuania.) But neither Japan nor the People's Republic of China constitutes a large enough share of East Asian trade to qualify as the obvious anchor either. East Asian countries have patterns of trade and investment that are too diversified to peg to any one major currency.

A basket peg is the obvious solution. ${ }^{28}$ In theory, a country ought to be able to capture the advantages of a fixed exchange rate with a basket peg, or at least the nominal anchor advantage. In practice, this seems not to be the case. First, basket pegs tend to be less firm and less credible than pegs to single currencies. Second, if such recent econometric studies as Rose (2000) are right, the big trade-promoting gain of fixed exchange rates arises when countries adopt a common currency, not just when the variability of the effective exchange rate is reduced. Third, as Ogawa and Ito (2000) and Ito (2001) point out, it is harder for one East Asian country to peg to a trade-weighted basket on its own if its neighbors continue to put a large weight on the dollar. In their model, a coordinated move by all East Asian countries to a common basket peg is better than a noncooperative equilibrium where each chooses the weights in its basket alone.

The idea of a common basket peg in East Asia has received a lot of attention. One could classify as favorably disposed, not just Ogawa and Ito (2000), but also Williamson (1999, 2001), Dornbusch and Park (1999), Kwan (1998, 2001), and several Japanese government officials. Others are skeptical. ${ }^{29}$

If Asian countries were eventually to peg their currencies to the same unit, they would reap the advantages of a common currency area, regardless of whether the anchor is a basket, a major currency like the yen, or some wholly new unit (such as a composite of the member currencies, the route that Europe took with the European Monetary System and the ecu, on its way to EMU and the euro). Some observers consider these advantages substantial. ${ }^{30}$ Others wonder if Asia satisfies the criteria for an optimum currency area. ${ }^{31}$

In any case, a rapid shift in which a substantial number of Asians peg tightly to a common currency unit in the near future is unlikely. It took Europe many decades to get to a common currency, notwithstanding that in the end, the euro 11 made the leap directly to EMU in January 1999 from a system of moderately wide bands. It is difficult to imagine the transition having been successful without the run-up that lasted several decades - including the "Snake" of the 1970s and the European Monetary System of the 1980s. These efforts helped change the optimum currency area parameters over time, to shift the logic in favor of currency union. So did parallel initiatives like the Schengen agreement on the movement of persons and the sequence of progressively more serious regional trading arrangements that culminated in the Single Market of 1992. By 1999, the

\footnotetext{
${ }^{28}$ E.g, Ito et al. (1998) and Ogawa and Sun (2002).

${ }^{29}$ DeBrouwer (2000).

30 E.g., Goto and Hamada (1994), 376-83.

31 Eichengreen and Bayoumi (1999), Frankel and Wei (1994, 1995) and Park and Park (1990).
} 
degrees of trade integration, labor mobility, correlation of shocks, and political solidarity were much higher than they had been 50 years earlier. Furthermore, throughout the postwar period, a strong political motivation drove European economic integration: the shared desire to ensure that there be no repeat of the three wars that Germany and France had fought over the preceding century. Even so, the path to EMU included innumerable crises, devaluations, revaluations, reforms, opting outs, opting back-ins, multispeeds, etc.

The more important question for Asia is whether some common loose arrangement could work for the medium term. Realistically, such an arrangement would have to allow the possibility-depending on circumstances - of individual countries opting in or opting out, of choosing their own individual degrees of rigidity on the spectrum between tight peg and loose target zone, and of possible individual balance-ofpayments crises along the way. It is neither possible nor desirable to specify one exchange rate regime to hold sway across Asia. The most that can be contemplated, in the medium run, is a sort of monetary framework for the region. The design of such an arrangement is of interest regardless of whether or not one views it as a possible transition to tighter monetary integration a la EMU.

What should be the anchor unit? That no Asian country has pegged to the yen, even loosely, must reflect, in part, sensible fears that such a country would be exposed to the large fluctuations in the value of the yen against other major currencies. The same goes for the idea of pegging to the Chinese renminbi. But a synthetic basket unit is also unlikely to do the job, at least at the beginning. Among the requirements for a currency to become used internationally is the condition that there is some nucleus country where the currency is on "home turf," i.e., where it is used for domestic transactions. To try to get a purely synthetic currency unit adopted internationally, no matter how well designed, is like trying to get Esperanto used as an international language. The IMF has learned this in its failed efforts to get the special drawing rights (SDR) adopted as an international currency anchor. ${ }^{32}$

Some country has to go first. Let us say it is Singapore. It could announce a commitment to a diversified basket peg, with explicit weights (on the dollar, yen, euro, and perhaps the renminbi). Countries in the region that wish to stabilize their exchange rates in terms of a basket could then choose the Singapore currency as that unit, rather than an individually concocted basket. Whether to peg or adopt an intermediate regime such as a target zone would be their choice to make. Their incentive to choose the Singapore currency as the anchor currency rather than the dollar or yen is that the weighted basket would prevent fluctuations in the dollar or yen from causing unwanted fluctuations in local effective exchange rates. As more countries joined, they would also reap the benefits of facilitated trade among each other. ASEAN members would probably be more tempted than others. ${ }^{33}$ Singapore's incentive to maintain the basket peg at the core, even if at times domestic economic considerations pointed to an effective appreciation or depreciation, would include the reaping of seigniorage. Singapore would in a sense serve as the region's bank.

\footnotetext{
${ }^{32}$ E.g., Mussa et al. (1996).

${ }^{33}$ ASEAN falls somewhat short of Europe in the economic criteria for an optimum currency area, and more than a little in the necessary political commitment. (Bayoumi et al. [2000]).
} 
A moderate gradual approach to East Asian monetary integration along these lines might not in the end work. But it would be more likely to work than an ambitious attempt to leap directly to a full-fledged regional currency union. Moderate solutions and gradual paths still generally work best. 


\section{References}

Bayoumi, Tamim, and Barry Eichengreen. 1994. One Money or Many? Analyzing the Prospects for Monetary Unification in Various Parts of the World. Studies in International Finance 76. Princeton University Press.

Bayoumi, Tamim, Barry Eichengreen, and Paolo Mauro. 2000. On Regional Arrangements for ASEAN, CEPR Discussion Paper 2411, April.

Benassy-Quere, Agnes. 1999. Exchange Rate Regimes and Policies: An Empirical Analysis. In Exchange Rate Policies in Emerging Asian Countries. edited by Stefan Collignon, Jean Pisani-Ferry, and Yung Chul Park. 40-64. (London: Routledge).

Bernanke, Ben, Thomas Laubach, Frederic Mishkin, and Adam Posen, Inflation Targeting: Lessons from the International Experience, Princeton University Press:

Princeton NJ, 1999.

Calvo, Guillermo. 1999.“On Dollarization, University of Maryland, April, available via internet http://www.bsos.umd.edu/econ/ciecpn5.pdf, .

Calvo, Guillermo, and Carmen Reinhart. 2000. When Capital Inflows Come to a Sudden Stop: Consequences and Policy Options. In Key Issues in Reform of the International Monetary System, 2001 edited by Peter Kenen and Alexander Swoboda. Washington, DC: International Monetary Fund.

2000. Fear of Floating. NBER Working Paper No. 7993, November. Revised version available via Internet: http://www.puaf.umd.edu/papers/reinhart.htm

Cooper, Richard. 1985. The Gold Standard: Historical Facts and Future Prospects. Brookings Papers on Economic Activity 1:1-45.

Council on Foreign Relations. 1999. Safeguarding Prosperity in a Global Financial System: The Future International Financial Architecture. Washington, DC: Institute for International Economics.

Crockett, Andrew. 1994. Monetary Policy Implications of Increased Capital Flows. In Changing Capital Markets: Implications for Monetary Policy, symposium sponsored by Federal Reserve Bank of Kansas City, Jackson Hole, August 1993.

Debelle, Guy. 2001. The Case for Inflation Targeting in East Asian Countries. In Future Directions for Monetary Policies in East Asia, edited by David Gruen and John Simon Sydney: Reserve Bank of Australia.

DeBrouwer, Gordon. 2000. Does a Formal Common-Basket Peg in East Asia Make Economic Sense. Asian-Japan Research Centre, Australian National University. 
Dekle, R. and M. Pradhan. 1997. Financial Liberalization and Money Demand in ASEAN Countries: Implications for Monetary Policy. IMF Working Paper 97/36.

Dornbusch, Rudiger, and Yung Chul Park. 1999. Flexibility or Nominal Anchors? In Exchange Rate Policies in Emerging Asian Countries, edited by Stefan Collignon, Jean Pisani-Ferry, and Yung Chul Park. London: Routledge

The Economist. 1999. Global Finance: Time for a Redesign? January 30:1-18.

Eichengreen, Barry. 1994. International Monetary Arrangements for the 21st Century, Washington, DC: Brookings Institution.

1999. Toward a New Financial Architecture: A Practical Post-Asia Agenda, Washington, DC: Institute for International Economics.

Eichengreen, Barry, and Tamim Bayoumi. 1999. Is Asia an Optimum Currency Area? Can it Become One? In Exchange Rate Policies in Emerging Asian Countries, edited by Stefan Collignon, Jean Pisani-Ferry, and Yung Chul Park. 347-366. London: Routledge.

Fischer, Stanley. 2001 . Exchange Rate Regimes: Is the Bipolar View Correct? Journal of Economic Perspectives 15(2): 3-24.

Frankel, Jeffrey. 1993a. Foreign Exchange Policy, Monetary Policy and Capital Market Liberalization in Korea. In Korean-US Financial Issues, US-Joint Korea-US Academic Symposium, Chwee Huay Ow-Taylor, Washington, DC: Korea Economic Institute of America, 91-107.

- 1993b. Liberalization of Korea's Foreign Exchange Markets, and the Role of Trade Relations with the United States. In Shaping a New Economic Relationship: The Republic of Korea and the United States, edited by Jongryn Mo and Ramon Myers, Stanford, CA: Hoover Institution Press, 120-142.

. 1995a. The Stabilizing Properties of a Nominal GNP Rule, Journal of Money, Credit and Banking 27, no. 2, May, 318-334.

- 1995b. Monetary Regime Choices for a Semi-Open Country. conference organized by Yung Chul Park. In Capital Controls, Exchange Rates and Monetary Policy in the World Economy, edited by Sebastian Edwards. Cambridge, UK: Cambridge University Press, 35-69.

1999. No Single Exchange Rate Regime is Right for All Countries or at All Times. Graham Lecture, Essays in International Finance, Princeton: Princeton University Press, 215.

- 2002. Should Gold-Exporters Peg Their Currencies to Gold? A study for the World Gold Council, London, June. 
Frankel, Jeffrey, and Andrew Rose. 2002. An Estimate of the Effect of Common Currencies on Trade and Income. Quarterly Journal of Economics (May) 437-66.

Frankel, Jeffrey, and Ayako Saiki. 2002. A Proposal to Anchor Monetary Policy by the Price of the Export Commodity. Journal of Economic Integration (September) 417-448.

Frankel, Jeffrey, Sergio Schmukler and Luis Servén. 2000. Verifiability and the Vanishing Intermediate Exchange Rate Regime. Brookings Trade Forum 2000, edited by Susan Collins and Dani Rodrik. Washington DC: Brookings Institution.

Frankel, Jeffrey, and Shang-Jin Wei. 1994. Yen Bloc or Dollar Bloc? Exchange Rate Policies of the East Asian Economies. In Macroeconomic Linkages: Savings, Exchange Rates, and Capital Flows, NBER - East Asia Seminar on Economics, Volume 3, edited by Takatoshi Ito and Anne Krueger. University of Chicago Press.

- 1995b. Is a Yen Bloc Emerging? In Economic Cooperation and Challenges in the Pacific, edited by Robert Rich, Washington, DC: Korea Economic Institute of America.

- 1997. ASEAN in a Regional Perspective. In Macroeconomic Issues facing ASEAN countries, edited by John Hicklin, David Robinson, and Anoop Singh Washington, DC: International Monetary Fund.

Friedman, Milton. 1953. The Case for Flexible Exchange Rates. In M.Friedman, Essays in Positive Economics. Chicago: University of Chicago Press, 157-203.

Ghosh, Atish, Anne-Marie Gulde, and Holger Wolf. 2000. Currency Boards: The Ultimate Fix? International Monetary Fund. Revised as "Currency Boards: More than a Quick Fix?" Economic Policy, 31 (October):270-335.

Goto, Junichi, and Koichi Hamada. 1994. Economic Preconditions for Asian Regional Integration. In Macroeconomic Linkages: Savings, Exchange Rates, and Capital Flows, NBER - East Asia Seminar on Economics, Volume 3, edited by Takatoshi Ito and Anne Krueger, 359-388. Chicago: University of Chicago Press.

Graham, Benjamin 1937. Storage and Stability. New York: McGraw Hill.

Graham, Frank. 1941. Transition to a Commodity Reserve Currency. American Economic Review 31(3):520-525.

Hausmann, Ricardo, Ugo Panizza, and Ernesto Stein. 2000. Why Do Countries Float the Way They Float? Inter-American Development Bank. (mimeo).

Hausmann, Ricardo, Michael Gavin, Carmen Pages-Serra, and Ernesto Stein. 1999. Why Do Countries Float the Way They Do? In New Initiatives to Tackle International Financial Turmoil. Interamerican Development Bank Annual Meetings of the Board of Governors, Paris. 
Ito, Takatoshi. 2001. Discussion of the Case for a Basket, Band and Crawl (BBC) Regime for East Asia. In Future Directions for Monetary Policies in East Asia, edited by David Gruen and John Simon. Sydney: Reserve Bank of Australia.

Ito, Takatoshi, Eiji Ogawa, and Yuri Sasaki. 1998. How Did the Dollar Peg Fail in Asia? Journal of the Japanese and International Economies, 12:256-304.

Keynes, John Maynard. 1938. The Policy of Government Storage of Foodstuffs and Raw Materials. Economic Journal (Sept.), 449-460.

Klein, Michael, and Nancy Marion. 1997. Explaining the Duration of Exchange-Rate Pegs. Journal of Development Economics 54(2):387-404.

Krugman, Paul. 1991. Target Zones and Exchange Rate Dynamics. Quarterly Journal of Economics, 106:669-682.

Kwan, C.H. 1998. The Yen, the Yuan, and the Asian Currency Crisis: Changing Fortune Between Japan and China. http://aparc.stanford.edu/docs/kwan.pdf.

—. 2001. Yen Bloc. Washington, DC: Brookings Institution Press.

Larrain, Felipe, and Andres Velasco. 2001. Exchange Rate Policy in Emerging Markets: The Case for Floating. Studies in International Economics no. 224, Princeton NJ: Princeton University Press.

Levy-Yeyati, Eduardo, and Federico Sturzenegger. 2001. To Float or to Trail: Evidence on the Impact of Exchange Rate Regimes. NBER Summer Institute, Universidad Torcuato de Tella.

Loayza, Norman, and Raimundo Soto. 2002. Inflation Targeting: Design, Performance, Challenges. Santiago: Central Bank of Chile.

Masson, Paul. 2001. Exchange Rate Regime Transitions. Journal of Development Economics, 64:571-586.

Masson, Paul, Miguel Savastavano, and Sunil Sharma. 1997. The Scope for Inflation Targeting in Developing Countries. IMF Working Paper 97/130, October.

McKibbin, Warwick, and Kanhaiya Singh. 2000. Issues in the Choice of a Monetary Regime for India. Presented at International Conference on Second Generation Reforms for India, Madras School of Economics, Chennai, India, December, 1999.

McKinnon, Ronald. 1963. Optimum Currency Areas. American Economic Review, 53:17724. 
- 2000. After the Crisis, The East Asian Dollar Standard Resurrected: An Interpretation of High-Frequency Exchange Rate Pegging. In Rethinking the East Asian Miracle, edited by Joseph Stiglitz and Shahid Yusuf. Oxford, UK: Oxford University Press.

Meltzer, Alan. 2000. Report of the International Financial Institution Advisory Commission. Submitted to the US Congress and US Department of the Treasury, March 8.

Minton-Beddoes, Zanny. 1999. From EMU to AMU? The Case for Regional Currency Blocs. Foreign Affairs. Vol. 78.

Mishkin, Frederic. 2000. Inflation Targeting in Emerging Market Countries. NBER Working Paper 7618, March.

Mundell, Robert. 1961. A Theory of Optimum Currency Areas. American Economic Review vol. 51 (November):509-517.

Mussa, Michael, James Boughton, and Peter Isard, eds. 1996. The Future of the SDR in Light of Changes in the International Financial System. Washington, DC: International Monetary Fund.

Obstfeld, Maurice, and Kenneth Rogoff. 1995. The Mirage of Fixed Exchange Rates. Journal of Economic Perspectives 9, no.4 (Fall):73-96.

Ogawa, Eiji, and Takatoshi Ito. 2000. On the Desirability of a Regional Currency Basket. NBER Working Paper 8002, November.

Ogawa, Eiji, and Lijian Sun. 2002. How Were Capital Flows Stimulated under the Dollar Peg System. In Regional and Global Capital Flows: Macroeconomic Causes and Consequences, edited by Takatoshi Ito and Anne Krueger. 151-190. Chicago: University of Chicago Press.

Ohno, Kenichi. 1999. Exchange Rate Management in Developing Asia. Working Paper 1 (January), Asian Development Bank Institute.

Park, Yung Chul, and Won Am Park. 1990. Exchange Rate Policy for the East Asian NICs. Working Paper 9010, Korea Development Institute.

Parsley, David, and Shangjin Wei. 2001. Limiting Currency Volatility to Stimulate Goods Market Integration. NBER Working Paper 8468, September.

Reinhart, Carmen. 2000. The Mirage of Floating Exchange Rates. American Economic Review 90 (2):65-70.

Reinhart, Carmen, and Kenneth Rogoff. 2002. The Modern History of Exchange Rate Arrangements: A Reinterpretation. Washington, DC: International Monetary Fund. 
Rogoff, Kenneth. 1985. "The Optimal Degree of Commitment to an Intermediate Monetary Target," Quarterly Journal of Economics 100, November, 1169-89.

Rose, Andrew. 2000. One Money, One Market? The Effect of Common Currencies on International Trade. Economic Policy, 30, April, 9-44.

Schliesser, Reinier, 2001, "Is There a New Generation of Intermediate Exchange Rate Regimes for Commodity-dependent Economies?" Some Ideas for an Optimal Choice of Exchange Rate Regime for Venezuela," Kennedy School of Government, March.

Stein, Ernesto and Jorge Streb. 1998. Political Stabilization Cycles in High Inflation Economies. Journal of Development Economics, 56:159-180.

- 1999. Elections and the Timing of Devaluations. Working paper, InterAmerican Development Bank.

Summers, Lawrence. 1999a. Testimony before the Senate Foreign Relations Subcommittee on International Economic Policy and Export/Trade Promotion, January 27.

- 1999b. Building an International Financial Architecture for the $21^{\text {st }}$ Century. Cato Journal, 18(3):321-330.

Svensson, Lars, 1995, "The Swedish Experience of an Inflation Target," in Inflation Targets, edited by Leo Leiderman and Lars Svensson (Centre for Economic Policy Research: London).

Takagi, Shinji. 1988. A Basket Policy: Operational Issues for Developing Countries. World Development, 16(2):271-79.

Tavlas, George. 1992. "The 'New' Theory of Optimal Currency Areas," International Monetary Fund, Washington, DC.

Williamson, John. 1996. The Crawling Band as an Exchange Rate Regime: Lessons from Chile, Colombia, and Israel, Washington, DC: Institute for International Economics.

- 1999. The Case for a Common Basket Peg for East Asian Countries. In Exchange Rate Policies in Emerging Asian Countries, edited by Stefan Collignon, Jean Pisani-Ferry, and Yung Chul Park. 327-343. London: Routledge.

- 2001. The Case for a Basket, Band and Crawl (BBC) Regime for East Asia. In Future Directions for Monetary Policies in East Asia, edited by David Gruen and John Simon. Sydney: Reserve Bank of Australia. 
Table 1: Estimated Effects of Adopting the Dollar or the Euro on Trade and Output

\begin{tabular}{|c|c|c|c|c|c|c|c|c|}
\hline \multirow{3}{*}{ Country } & \multicolumn{3}{|c|}{ Actual Data } & \multicolumn{4}{|c|}{ Estimated Impacts } & \multirow[b]{4}{*}{$\begin{array}{c}\text { Largest non-\$/€ } \\
\text { partner (\% trade) }\end{array}$} \\
\hline & \multirow[b]{2}{*}{ Openness } & \multicolumn{2}{|c|}{ Trade with: } & \multicolumn{2}{|c|}{ Trade effect: } & \multicolumn{2}{|c|}{ GDP effect: } & \\
\hline & & \$ zone & $€$ zone & $\begin{array}{c}\text { Adopt } \\
\$\end{array}$ & $\begin{array}{c}\text { Adopt } \\
€\end{array}$ & $\begin{array}{c}\text { Adopt } \\
\$\end{array}$ & $\begin{array}{c}\text { Adopt } \\
€\end{array}$ & \\
\hline & \begin{tabular}{|l|} 
\% of \\
GDP \\
\end{tabular} & $\%$ & $\%$ & $\begin{array}{l}\text { \% of } \\
\text { GDP }\end{array}$ & \begin{tabular}{|l|}
$\%$ of \\
GDP \\
\end{tabular} & \begin{tabular}{|l|}
$\%$ of \\
GDP \\
\end{tabular} & \begin{tabular}{|c|} 
\%of \\
GDP \\
\end{tabular} & \\
\hline Albania & 47 & 3 & 75 & 51 & 153 & 1 & 35 & \\
\hline Algeria & 59 & 13 & 62 & 82 & 169 & 8 & 36 & \\
\hline Angola & 110 & 50 & 34 & 275 & 222 & 54 & 37 & \\
\hline Bangladesh & 37 & 20 & 21 & 59 & 60 & 7 & 8 & \\
\hline Belize & 103 & 44 & 8 & 239 & 128 & 45 & 8 & \\
\hline Brazil & 15 & 23 & 24 & 25 & 26 & 3 & 4 & \\
\hline Burundi & 33 & 7 & 75 & 40 & 107 & 2 & 25 & \\
\hline Cambodia & 80 & 2 & 8 & 85 & 99 & 2 & 6 & Singapore (33) \\
\hline Chile & 55 & 21 & 17 & 90 & 83 & 11 & 9 & \\
\hline $\begin{array}{r}\text { People's } \\
\text { Republic of } \\
\end{array}$ & & 12 & 11 & 56 & 52 & 5 & 4 & Hong Kong, China \\
\hline Colombia & $\frac{40}{36}$ & $\frac{13}{38}$ & $\frac{11}{18}$ & $\frac{10}{77}$ & $\frac{35}{55}$ & 14 & 6 & \\
\hline Congo (Zaire) & 59 & 13 & 57 & 82 & 160 & 8 & 33 & \\
\hline Costa Rica & 86 & 53 & 17 & 223 & 130 & 45 & 14 & \\
\hline Djibouti & 99 & 3 & 38 & 108 & 212 & 3 & 37 & \\
\hline Dominican Rep. & 63 & 76 & 7 & 207 & 76 & 47 & 4 & \\
\hline Egypt & 53 & 18 & 38 & 82 & 113 & 9 & 20 & \\
\hline Eq'l Guinea & 154 & 21 & 45 & 251 & 362 & 32 & 69 & \\
\hline Ethiopia & 38 & 12 & 53 & 52 & 98 & 5 & 20 & \\
\hline Fiji & 115 & 10 & 4 & 150 & 129 & 11 & 5 & Australia (34) \\
\hline Gambia & 132 & 2 & 51 & 140 & 334 & 3 & 67 & \\
\hline Ghana & 60 & 12 & 40 & 82 & 132 & 7 & 24 & \\
\hline Guinea & 48 & 15 & 56 & 70 & 129 & 7 & 27 & \\
\hline Guyana & 211 & 28 & 12 & 388 & 287 & 58 & 25 & \\
\hline Haiti & 36 & 67 & 13 & 108 & 50 & 24 & 5 & \\
\hline Honduras & 91 & 52 & 17 & 233 & 137 & 47 & 15 & \\
\hline Hungary & 76 & 4 & 71 & 85 & 238 & 3 & 53 & \\
\hline Iceland & 67 & 11 & 34 & 89 & 135 & 7 & 23 & \\
\hline India & 28 & 17 & 29 & 42 & 52 & 5 & 8 & \\
\hline Indonesia & 52 & 13 & 15 & 72 & 75 & 7 & 8 & Japan (25) \\
\hline Iran & 36 & 1 & 40 & 37 & 79 & 0 & 14 & \\
\hline Israel| & 69 & 25 & 38 & 121 & 148 & 17 & 26 & \\
\hline Jamaica & 136 & 53 & 9 & 352 & 173 & 71 & 12 & \\
\hline Jordan & 126 & 7 & 24 & 152 & 217 & 9 & 30 & \\
\hline Kenya & 73 & 6 & 35 & 86 & 150 & 4 & 25 & \\
\hline Republic of & 67 & 22 & 11 & 111 & 89 & 15 & 7 & \\
\hline
\end{tabular}




\begin{tabular}{|c|c|c|c|c|c|c|c|c|}
\hline \multirow{3}{*}{ Country } & \multicolumn{3}{|c|}{ Actual Data } & \multicolumn{4}{|c|}{ Estimated Impacts } & \multirow[b]{4}{*}{$\begin{array}{c}\text { Largest non-\$/€ } \\
\text { partner (\% trade) }\end{array}$} \\
\hline & \multirow[b]{2}{*}{ Openness } & \multicolumn{2}{|c|}{ Trade with: } & \multicolumn{2}{|c|}{ Trade effect: } & \multicolumn{2}{|c|}{ GDP effect: } & \\
\hline & & \$ zone & € zone & \begin{tabular}{|c|} 
Adopt \\
$\$$
\end{tabular} & $\begin{array}{c}\text { Adopt } \\
€\end{array}$ & $\begin{array}{c}\text { Adopt } \\
\$\end{array}$ & $\begin{array}{c}\text { Adopt } \\
€\end{array}$ & \\
\hline & $\begin{array}{l}\% \text { of } \\
\text { GDP }\end{array}$ & $\%$ & $\%$ & \begin{tabular}{|l|}
$\%$ of \\
GDP
\end{tabular} & $\begin{array}{l}\text { \% of } \\
\text { GDP }\end{array}$ & $\begin{array}{l}\% \text { of } \\
\text { GDP }\end{array}$ & $\begin{array}{l}\text { \%of } \\
\text { GDP }\end{array}$ & \\
\hline Korea & & & & & & & & \\
\hline Kuwait & 104 & 19 & 24 & 163 & 179 & 20 & 25 & \\
\hline Lao PDR & 61 & 2 & 16 & 65 & 90 & 1 & 10 & Thailand (53 \\
\hline Lebanon & 77 & 12 & 51 & 105 & 195 & 9 & 39 & \\
\hline Madagascar & 55 & 4 & 55 & 62 & 146 & 2 & 30 & \\
\hline Malawi & 73 & 8 & 26 & 91 & 130 & 6 & 19 & South Africa (31 \\
\hline Malaysia & 194 & 17 & 10 & 293 & 252 & 33 & 19 & Singapore (24 \\
\hline Mauritania & 112 & 5 & 60 & 129 & 314 & 6 & 67 & \\
\hline Mauritius & 122 & 1 & 36 & 126 & 254 & 1 & 43 & \\
\hline Mexico & 59 & 79 & 6 & 199 & 70 & 46 & 4 & \\
\hline Mongolia & 106 & 8 & 17 & 131 & 160 & 8 & 18 & China (30 \\
\hline Morocco & 61 & 5 & 59 & 70 & 169 & 3 & 36 & \\
\hline Mozambique & 88 & 7 & 22 & 106 & 146 & 6 & 19 & South Africa (47 \\
\hline Myanmar & 3 & 3 & 5 & 3 & 3 & 0 & 0 & Singapore (24 \\
\hline Nepal & 59 & 12 & 22 & 80 & 98 & 7 & 13 & \\
\hline Nicaragua & 91 & 38 & 16 & 195 & 135 & 34 & 14 & \\
\hline Nigeria & 30 & 35 & 34 & 62 & 61 & 10 & 10 & \\
\hline Pakistan & 36 & 12 & 20 & 49 & 58 & 4 & 7 & \\
\hline $\begin{array}{r}\text { Papua New } \\
\text { Guinea }\end{array}$ & 103 & 3 & 11 & 112 & 137 & 3 & 11 & Australia (36 \\
\hline Paraguay & 48 & 19 & 8 & 75 & 60 & 9 & 4 & Brazil (32 \\
\hline Peru & 28 & 24 & 18 & 48 & 43 & 7 & 5 & \\
\hline Philippines & 81 & 24 & 10 & 139 & 105 & 19 & 8 & \\
\hline Poland & 50 & 3 & 60 & 55 & 140 & 1 & 30 & \\
\hline Romania & 59 & 4 & 62 & 66 & 169 & 2 & 36 & \\
\hline Rwanda & 36 & 23 & 50 & 61 & 90 & 8 & 18 & \\
\hline Saudi Arabia & 72 & 20 & 21 & 115 & 117 & 14 & 15 & \\
\hline Seychelles & 104 & 0 & 16 & 104 & 154 & 0 & 16 & Yemen $(20$ \\
\hline Sierra Leone & 39 & 14 & 54 & 55 & 102 & 5 & 21 & \\
\hline Singapore & 356 & 16 & 10 & 527 & 463 & 56 & 35 & \\
\hline South Africa & 50 & 10 & 29 & 65 & 94 & 5 & 14 & \\
\hline Sri Lanka & 82 & 17 & 16 & 124 & 121 & 14 & 13 & \\
\hline Tanzania & 63 & 6 & 26 & 74 & 112 & 4 & 16 & \\
\hline Thailand & 90 & 14 & 13 & 128 & 125 & 12 & 12 & Japan (24 \\
\hline $\begin{array}{r}\text { Trinidad \& } \\
\text { Tobago } \\
\end{array}$ & 97 & 42 & 9 & 219 & 123 & 40 & 9 & \\
\hline Tunisia & 93 & 3 & 75 & 101 & 302 & 3 & 69 & \\
\hline Turkey & 44 & 9 & 46 & 56 & 105 & 4 & 20 & \\
\hline Uganda & 32 & 4 & 58 & 36 & 88 & 1 & 18 & \\
\hline
\end{tabular}




\begin{tabular}{|c|c|c|c|c|c|c|c|c|}
\hline \multirow{3}{*}{ Country } & \multicolumn{3}{|c|}{ Actual Data } & \multicolumn{4}{|c|}{ Estimated Impacts } & \multirow[b]{4}{*}{$\begin{array}{c}\text { Largest non-\$ } / € \\
\text { partner }(\% \text { trade) }\end{array}$} \\
\hline & \multirow[b]{2}{*}{ Openness } & \multicolumn{2}{|c|}{ Trade with: } & \multicolumn{2}{|c|}{ Trade effect: } & \multicolumn{2}{|c|}{ GDP effect: } & \\
\hline & & \$ zone & $€$ zone & $\begin{array}{c}\text { Adopt } \\
\$\end{array}$ & $\begin{array}{c}\text { Adopt } \\
€\end{array}$ & \begin{tabular}{|c|} 
Adopt \\
\$
\end{tabular} & \begin{tabular}{|c|} 
Adopt \\
$€$
\end{tabular} & \\
\hline & $\begin{array}{l}\text { \% of } \\
\text { GDP }\end{array}$ & $\%$ & $\%$ & $\begin{array}{l}\text { \% of } \\
\text { GDP }\end{array}$ & $\begin{array}{l}\text { \% of } \\
\text { GDP }\end{array}$ & $\begin{array}{l}\text { \% of } \\
\text { GDP }\end{array}$ & $\begin{array}{l}\text { \%of } \\
\text { GDP }\end{array}$ & \\
\hline Uruguay & 38 & 9 & 18 & 48 & 59 & 3 & 7 & Brazil (29) \\
\hline Venezuela & 48 & 50 & 10 & 120 & 62 & 24 & 5 & \\
\hline Viet Nam & 83 & 4 & 16 & 93 & 123 & 3 & 13 & Japan (19) \\
\hline Yemen & 73 & 7 & 13 & 88 & 101 & 5 & 9 & $\begin{array}{r}\text { Republic of Korea } \\
\text { (14) }\end{array}$ \\
\hline Zambia & 91 & 5 & 17 & 105 & 137 & 5 & 15 & South Africa (22) \\
\hline Zimbabwe & 91 & 4 & 21 & 102 & 148 & 4 & 19 & South Africa (36) \\
\hline Average $^{b}$ & 73 & 19 & 29 & 114 & 134 & 13 & 20 & \\
\hline
\end{tabular}

Notes:

(i) Assumptions: currency union triples trade; .33 effect of openness on GDP.

(ii)The estimation, which uses 1995 trade date, is described in Frankel and Rose (2002).

(iii)This version of the table is based on the Kennedy School working paper version, RWP01-013, April 2001.

a Lao People's Democratic Republic.

${ }^{\mathrm{b}}$ Industrialized countries that float are included in the average, but not reported in the table.

Source: Frankel and Rose (2002), working paper version. 
Table 2: Three Empirical Studies of Growth Rates Across Regimes

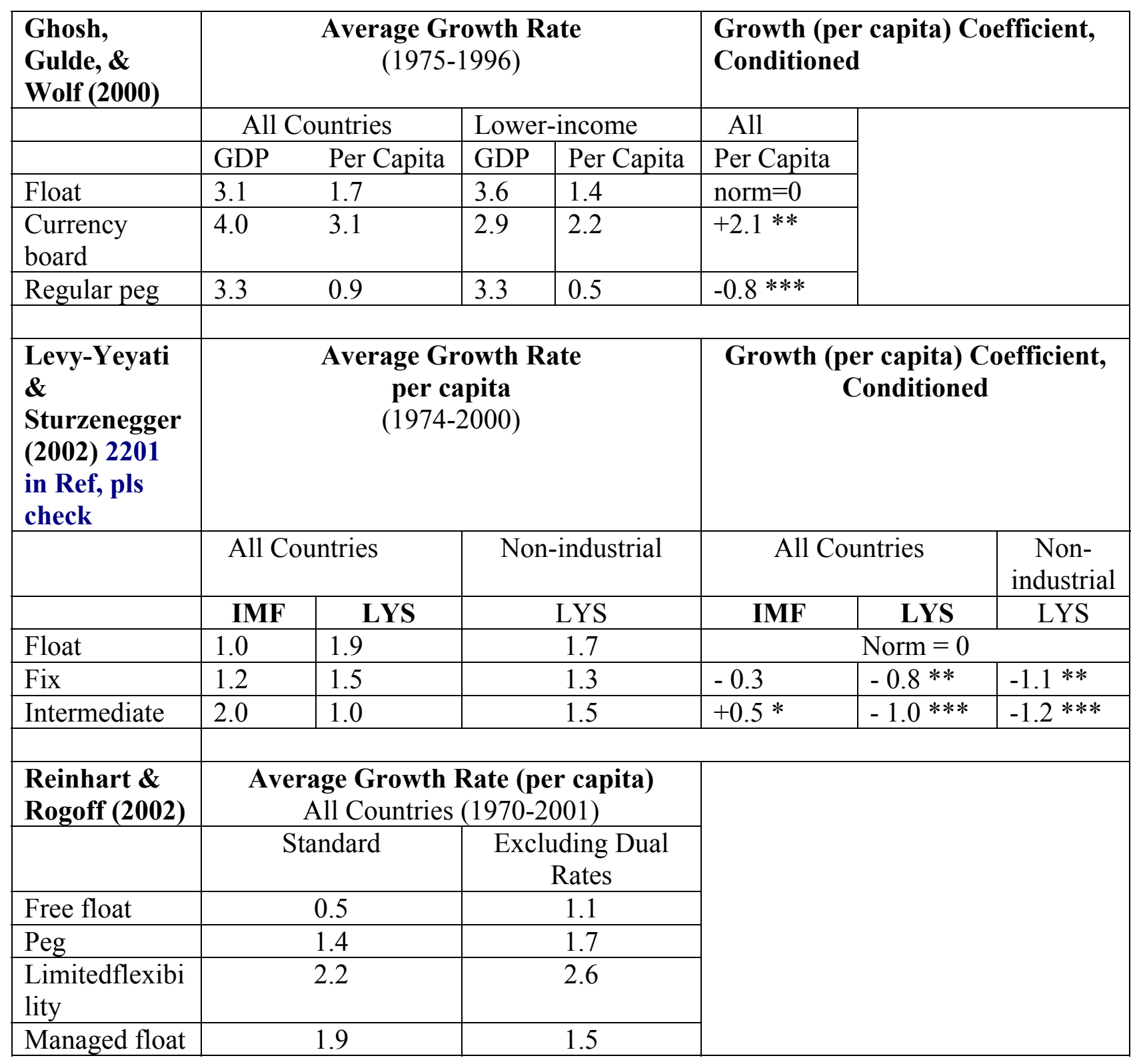

IMF = International Monetary Fund, LYS = Levy-Yeyati and Sturzenegger system.

Note: Significant at (*) $10 \%$ level, $(* *) 5 \%$ level, and (***)1\% level. 
Table 3: Correlations Among Regime Classification Schemes (Frequency of outright coincidence, in percentage, is given in parenthesis.)

\begin{tabular}{|c|c|c|c|c|}
\hline & IMF & Ghosh & LY-S & R-R \\
\hline \multirow{2}{*}{ IMF } & 1.00 & & & \\
& $(100.0)$ & & & \\
\hline \multirow{2}{*}{ Ghosh } & 0.60 & 1.00 & & \\
& $(55.1)$ & $(100.0)$ & & \\
\hline \multirow{2}{*}{ LY-S } & 0.28 & 0.13 & 1.00 & \\
& $(41.0)$ & $(35.3)$ & $(100.0)$ & 1.00 \\
\multirow{2}{*}{ R-R } & 0.33 & 0.34 & 0.41 & $(100.0)$ \\
\hline
\end{tabular}

The table shows the correlations and percentage of coincidences between four systems of annual classification of exchange rate regimes: IMF (end-of-period values); Ghosh, Gulde, Ostry, and Wolf (Ghosh); Levy Yeyati and Sturzenegger (LY-S); and Reinhart and Rogoff (R-R). The sample includes 47 countries: Argentina, Australia, Austria, Belgium, Bolivia, Brazil, Canada, Chile, Colombia, Costa Rica, Denmark, Dominican Republic, Ecuador, Egypt, El Salvador, Finland, Germany, Greece, Guatemala, Hong Kong, Indonesia, Ireland, Israel, Italy, Japan, Korea, Kuwait, Lebanon, Malaysia, Mauritius, Mexico, Netherlands, New Zealand, Norway, Paraguay, Philippines, Portugal, Singapore, South Africa, Spain, Sweden, Switzerland, Thailand, Turkey, United Kingdom, Uruguay, and Venezuela. The period considered is 1974-1998 for the IMF classification, 1974-1995 for the Ghosh classification, and 1974-2000 for the LY-S and $\mathrm{R}-\mathrm{R}$ classifications. Exchange rate regimes are classified as fixed, intermediate, or floating. The R-R classification was collapsed into these three categories according to the Appendix Table.

Sources for classifications: IMF; Ghosh, Gulde, Ostry, \& Wolf (1996); Levy Yeyati \& Sturzenegger (2000); and Reinhart \& Rogoff (2002). Table prepared by Marina Halac \& Sergio Schmukler. 